\title{
Gambaran Penderita Fraktur Maksilofasial di RSUD Arifin Achmad Pekanbaru Periode Januari 2009-desember 2011
}

\author{
Nanda Juwita ${ }^{1}$, Welli Zulfikar ${ }^{2}$, Tuti Restuastuti ${ }^{3}$
}

\begin{abstract}
Maxillofacial fracture can cause facial deformity up to threat life saving thing due to disturbance of airway. Maxillofacial fracture is most happen in productive age because of more high activities. This research purpose to know the demography maxillofacial fracture patient. This research was a descriptive retrospective study which was done at Arifin Achmad General Hospital Pekanbaru. Base on secondary data research results that take from patient's medical record from 195 patients maxillofacial fracture, only 135 cases include to criteria. Maxillofacial fracture 117 patients were men (86,67\%) and 18 patients were women (13,33\%). Most of patients were 11-20 years old 53 cases (39,26\%). Traffic accident was the most etiology maxillofacial fracture 128 cases $(94,81 \%$.). Most often clinical manifestations were edema of soft tissue, epistaxis, deformity and malocclusion. Mandibula fracture as the first top case were 62 patients $(45,92 \%)$. Surgery (ORIF) was mostly done in 87 patient $(64,45 \%)$, include combine with close reduction.
\end{abstract}

Key words: maxillofacial fracture, overview of maxillofacial fracture.

\section{PENDAHULUAN}

Maksilofasial merupakan bagian yang penting bagi kehidupan manusia. ${ }^{1}$ Maksilofasial dibentuk oleh tulang-tulang wajah atau tengkorak bagian depan, sehingga apabila terjadi fraktur dapat mengakibatkan suatu kelainan pada bentuk wajah yang menyebabkan gangguan estetik pada wajah yang tidak jarang mengakibatkan deformitas berat dan meninggalkan kecacatan bahkan dapat mengancam jiwa seperti akibat gangguan saluran napas bagian atas dan otak..$^{1,2,3}$ Akibat trauma maksilofasial yang sering kompleks dan melibatkan beberapa organ penting, sehingga penanganan harus intensif dan holistik. ${ }^{1,4}$ Fraktur pada maksilofasial bisa terjadi hanya satu tempat ataupun multipel/ kompleks, akibat benturan dengan kekuatan rendah atau akibat kekuatan tinggi ( $>50$ kekuatan gravitasi). 1

Struktur tulang maksilofasial yang pipih dan menonjol menjadikannya lebih rentan terjadi frakturkarena menjadi sasaran penganiayaan dan benturan. Sekitar $70 \%$ kecelakaan lalu lintas disertai trauma kepala leher, dan yang paling sering

\footnotetext{
${ }^{1}$ Mahasiswa Fakultas Kedokteran Universitas Riau

${ }^{2}$ SMF Bedah Fakultas Kedokteran Universitas Pekanbaru

${ }^{3}$ Bagian IKM-KK Fakultas Kedokteran Universitas Riau
}

mengalami cedera adalah bagian maksilofasial terutama mandibula. ${ }^{1}$ Angka kejadian fraktur maksilofasial 6\% dari seluruh trauma yang ditangani oleh SMF Ilmu Bedah RSUD Dr. Soetomo, Surabaya. ${ }^{5,6}$ Dari data rekam Medik RSUD Arifin Achmad dari tahun 2009 hingga 2011 didapatkan jumlah penderita fraktur maksilofasial sebanyak 195 penderita, tetapi hanya 135 pasien yang termasuk kriteria inklusi. Kejadian fraktur maksilofasial sebanyak 82,46\% disebabkan oleh kecelakaan lalu lintas.

Faktor umur dan jenis kelamin dilaporkan memiliki kaitan dengan insiden fraktur maksilofasial.Frekuensi fraktur maksilofasial pada kelompok usia produktif yaitu kelompok usia anak, remaja hingga dewasa muda relatif lebih tinggi. ${ }^{1,6}$ Penelitian oleh Hwang (2010) di Rumah Sakit Pendidikan Universitas Inha, Korea Selatan bahwa morbiditas tertinggi pada fraktur maksilofasial dialami oleh kelompok umur 21-30 tahun (29\%), berbeda dengan penelitian Erol (2002) dari tahun 1978-2002 di Bagian Bedah Mulut dan Maksilofasial, Fakultas Kedokteran Gigi Universitas Dicle, Turki bahwa fraktur maksilofasial paling banyak ditemukan pada usia anak-anak yaitu 0-10 tahun $(27,6 \%)$, terutama pada musim panas karena anak-anak berlibur dan banyak bermain 
diluar rumah sehingga lebih beresiko untuk jatuh dan terjadi fraktur maksilofasial. ${ }^{7,8}$ Sedangkan penelitian di Royal Adelaide Hospital, Australia bahwa penderita fraktur maksilofasial terbanyak adalah kelompok usia 20-29 tahun. ${ }^{1}$ Penelitian Reksoprawiro (2006)perbandingan pria dan wanita yang mengalami fraktur maksilofasial adalah 6:1.5,6 Penelitian di Royal Adelaide Hospital, Australia (1989-1992) perbandingan laki-laki dan perempuan adalah $4: 1$, sedangkan penelitian di Waikato Hospital, New Zealand (2000) 80\% penderita fraktur maksilofasial adalah lakilaki.Sesuai dengan kepustakaan bahwa insidensi fraktur maksilofasial terjadi lebih banyak pada lakilaki dari pada perempuan, hal ini karena laki-laki lebih banyak berada diluar rumah, sehingga lebih beresiko terjadi fraktur maksilofasial karena kegiatannya. ${ }^{1,9}$.

Tujuan dari penelitian ini adalah untuk mengetahui gambaran penderita fraktur maksilofasial berupa umur, jenis kelamin, etiologi, jenis fraktur, gejala klinis dan penatalaksanaan di Bagian Bedah RSUD Arifin Achmad periode Januari 2009 - Desember 2011.

\section{METODE PENELITIAN}

Desain penelitian ini adalah deskriptif retrospektif menggunakan data sekunder berupa catatan rekam medik penderita fraktur maksilofasial di Bagian Bedah yang tercatat di Bagian Rekam Medik RSUD Arifin Achmad Pekanbaru periode Januari 2009 - Desember 2011 dan dilaksanakan pada bulan Oktober 2011 - Maret 2012. sampel pada penelitian ini adalah semua data rekam medik yang didiagnosis fraktur maksilofasial di Bagian Bedah RSUD Arifin Achmad Pekanbaru periode Januari 2009 - Desember 2011. Besar sampel sebanyak 135 penderita. Data-data yang telah didapatkan dikelompokkan sesuai dengan variabel yang ingin diteliti dan diolah secara manual dan komputerisasi untuk selanjutnya disajikan dalam bentuk tabel distribusi frekuensi. Analisis data dilakukan secara deskriptif dengan menggunakan tabel distribusi frekuensi berdasarkanjenis kelamin, umur, etiolofi, jenis fraktur, gejala klinis dan penatalaksanaan.

\section{HASIL PENELITIAN}

Gambaran karakteristik individu penderita fraktur maksilofasial

Tabel 4.1 Gambaran insidensi penderita fraktur maksilofasial

\begin{tabular}{lc}
\hline \multicolumn{1}{c}{ Gambaran kasus } & Frekiens (N) \\
\hline Angka kejadian trauma & 3146 \\
Angka kejadian fraktur maksilofasial & 195 \\
\hline
\end{tabular}

Berdasarkan tabel 4.1 di atas dapat dilihat bahwa penderita fraktur maksilofasial adalah sebanyak 195 orang sedangkan jumlah penderita trauma secara keseluruhan yang ditangani oleh Bagian Bedah RSUD Arifin Achmad Pekanbaru adalah 3146 orang. Sehingga insidensi fraktur maksilofasial di RSUD Arifin Achmad Pekanbaru adalah $195 / 3146 \times 100 \%=6,19 \%$ dari seluruh trauma yang ditangani di Bagian Bedah RSUD Arifin Achmad Pekanbaru. 
Tabel 4.2 Gambaran distribusi karakteristik penderita fraktur maksilofasial

\begin{tabular}{|c|c|c|}
\hline Gambaran kasus & Jumlah $(\mathrm{N})$ & Persenta se (\%) \\
\hline \multicolumn{3}{|l|}{ Jenis kelamin } \\
\hline a. Laki -laki & 117 & 86,67 \\
\hline b. Perempuan & 18 & 13,33 \\
\hline Total & 135 & 100,00 \\
\hline \multicolumn{3}{|l|}{ Kelompok umur } \\
\hline a. $0-10$ & 8 & 5,92 \\
\hline b. $11-20$ & 53 & 39,26 \\
\hline c. $21-30$ & 37 & 27,41 \\
\hline d. $31-40$ & 17 & 12,59 \\
\hline e. $41-50$ & 15 & 11,11 \\
\hline f. $51-60$ & 4 & 2,96 \\
\hline$>60$ & 1 & 0,74 \\
\hline Total & 135 & 100,00 \\
\hline \multicolumn{3}{|l|}{ Etiologi } \\
\hline a. Kecelakaan lalulintas & 128 & 94,81 \\
\hline - Motor & 110 & 81,48 \\
\hline - Mobil, dil & 18 & 13,33 \\
\hline b. Pengani ayaan & 1 & 0,74 \\
\hline c. Kecelakaan Kerja & 2 & 1,48 \\
\hline d. Kecelakaan olahraga & 1 & 0,74 \\
\hline e. Jatuh & 3 & 2,22 \\
\hline Total & 135 & 100,00 \\
\hline \multicolumn{3}{|l|}{ Jenis fraktur } \\
\hline Froktur thinggal & 98 & 72,59 \\
\hline a. Fraktur nasal & 18 & 13,33 \\
\hline \multirow{2}{*}{$\begin{array}{l}\text { b. Fraktur maksila } \\
\text { - Fraktur dento al veol ar } \\
\text { sup erior }\end{array}$} & 6 & 4,44 \\
\hline & 4 & 2,96 \\
\hline \multicolumn{3}{|l|}{ c. Fraktur kompleks zigoma } \\
\hline $\begin{array}{l}\text { - Fraktur zigoma } \\
\text { - Fraktur }\end{array}$ & 2 & 1,48 \\
\hline $\begin{array}{l}\text { zigomatikomaksilaris } \\
\text { kompleks }\end{array}$ & 6 & 4,44 \\
\hline \multirow{2}{*}{$\begin{array}{l}\text { d. Fraktur mandibul a } \\
\text { - Fraktur dento al veol ar } \\
\text { inferior }\end{array}$} & 56 & 41,48 \\
\hline & 6 & 4,44 \\
\hline Fraktur multipel & 37 & 27,41 \\
\hline e. Fraktur panfasial & 6 & 4,44 \\
\hline $\begin{array}{l}\text { f. Fraktur } \\
\text { Nasoorbitoethmoidalis }\end{array}$ & 1 & 0,74 \\
\hline g. Frakur maksila+zigoma & 15 & 11,11 \\
\hline h. Fraktur mandibul atmaksila & 6 & 4,44 \\
\hline i. Fraktur mandibul a + zigoma & 2 & 1,48 \\
\hline j. Fraktur nasal+zigoma & 3 & 2,22 \\
\hline k. Fraktur nasal+mandibula & 1 & 0,74 \\
\hline 1. Fraktur nasal+maksila & 3 & 2,22 \\
\hline Total & 135 & 100,00 \\
\hline
\end{tabular}




\begin{tabular}{rlc}
\hline Gejala klinis & & \\
a. Depresi tulang hidung & 4 & 1,07 \\
b. Edema & 57 & 15,32 \\
c. Deviasi septum & 5 & 1,34 \\
d. Epistaksis & 48 & 12,90 \\
e. Maloklusi & 45 & 12,09 \\
f. Diplopia & 1 & 0,27 \\
g. Floating maxilla & 1 & 0,27 \\
h. Edema periorbita & 16 & 4,30 \\
i. ekimosis & 2 & 0,53 \\
j. Enoftalmus & 0 & 0 \\
k. Pendataran sisi lateral pipi & 1 & 0,27 \\
1. Nyeri & 30 & 8,06 \\
m. Trismus & 10 & 2,68 \\
n. Laserasi intraoral & 43 & 11,56 \\
o. Nyeri mengunyah & 32 & 8,60 \\
p. Gigi dapat digerakkan & 18 & 4,84 \\
q. Deformitas & 45 & 12,09 \\
r. Krepitasi & 7 & 1,88 \\
s. Step off & 7 & 1,88 \\
\hline Penatalaksanaan & & \\
a. Operatif & 51 & 37,78 \\
b. Kombinasi reduksi terbuka & & \\
b. dan tertutup & 36 & 26,67 \\
c. Close reduction & 26 & 19,26 \\
d. Konservatif & 22 & 16,29 \\
Total & & \\
\hline
\end{tabular}

веraasarkan tabeı 4.2 d1 atas dapat diınat bahwa pasien fraktur maksilofasial terbanyak adalah laki-laki sebanyak 117 kasus $(86,67 \%)$, sedangkan perempuan sebanyak 18 kasus (13,33\%).Penderita fraktur maksilofasial terbanyak adalah pada umur 11-20 tahun $(39,26 \%)$ dan 21-30 (27,41\%). Penyebab fraktur maksilofasialterbanyak adalah karena kecelakaan lalulintas $(94,81 \%)$ yang sebagian besar karena kecelakaan sepeda motor $(81,48 \%)$. Jenis fraktur tersering pada tulang-tulang maksilofasial adalah fraktur mandibula $(45,92 \%)$.Gejala klinis pasien fraktur maksilofasial terbanyak adalah edema jaringan lunak $(15,13 \%)$, epistaksis $(12,90 \%)$ kemudian deformitas dan maloklusi masing-masing sebesar 12,09\%.Penatalaksanaan pasien fraktur maksilofasial terbanyak adalah operatif/reduksi terbuka dengan Open Reduction and Internal Fixation dengan plate and screw maupun wire sebanyak 51 pasien $(37,78 \%)$ dan teknik kombinasi reduksi terbuka dan tertutup sebanyak 36 pasien $(26,67 \%)$. Umur termuda yang dirawat adalah 2 tahun dan umur tertua 69 tahun. 
Diagram 4.1: Distribusi penderita fraktur maksilofasial berdasarkan jenis kelamin di RSUD Arifin Achmad Periode Januari 2009-Desember 2011.

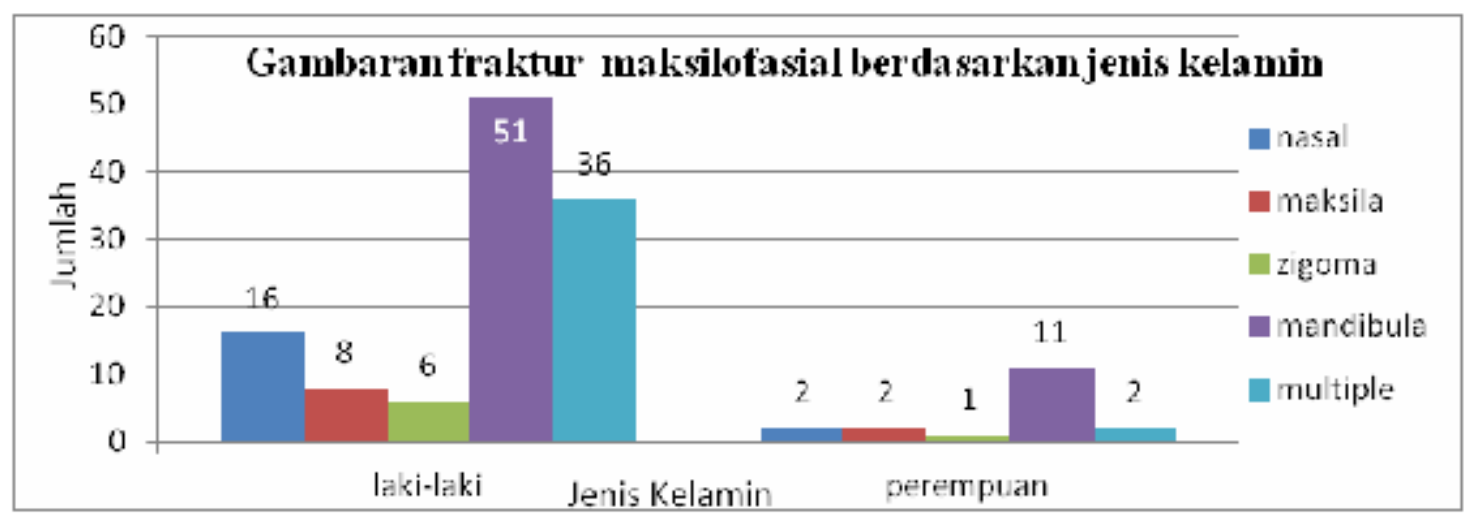

Diagram 4.2: Distribusi penderita fraktur maksilofasial berdasarkan umur di RSUD Arifin Achmad Periode Januari 2009-Desember 2011.

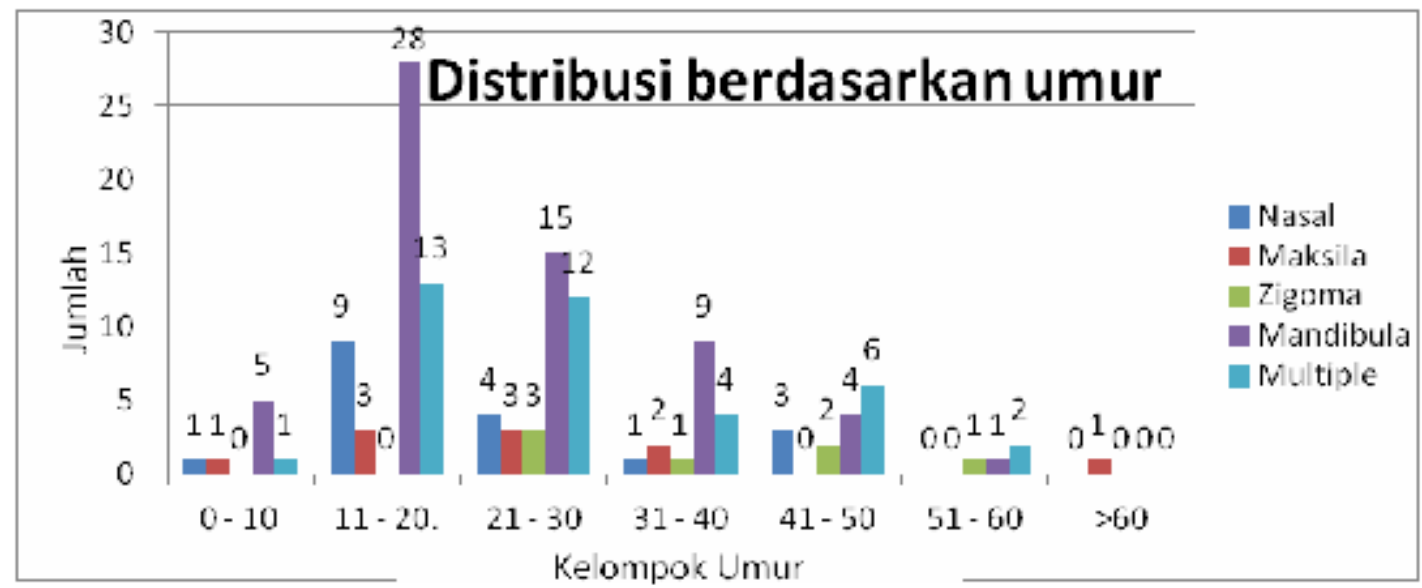

Diagram 4.3: Distribusi penderita fraktur maksilofasial berdasarkan penyebab di RSUD Arifin Achmad Periode Januari 2009-Desember 2011.

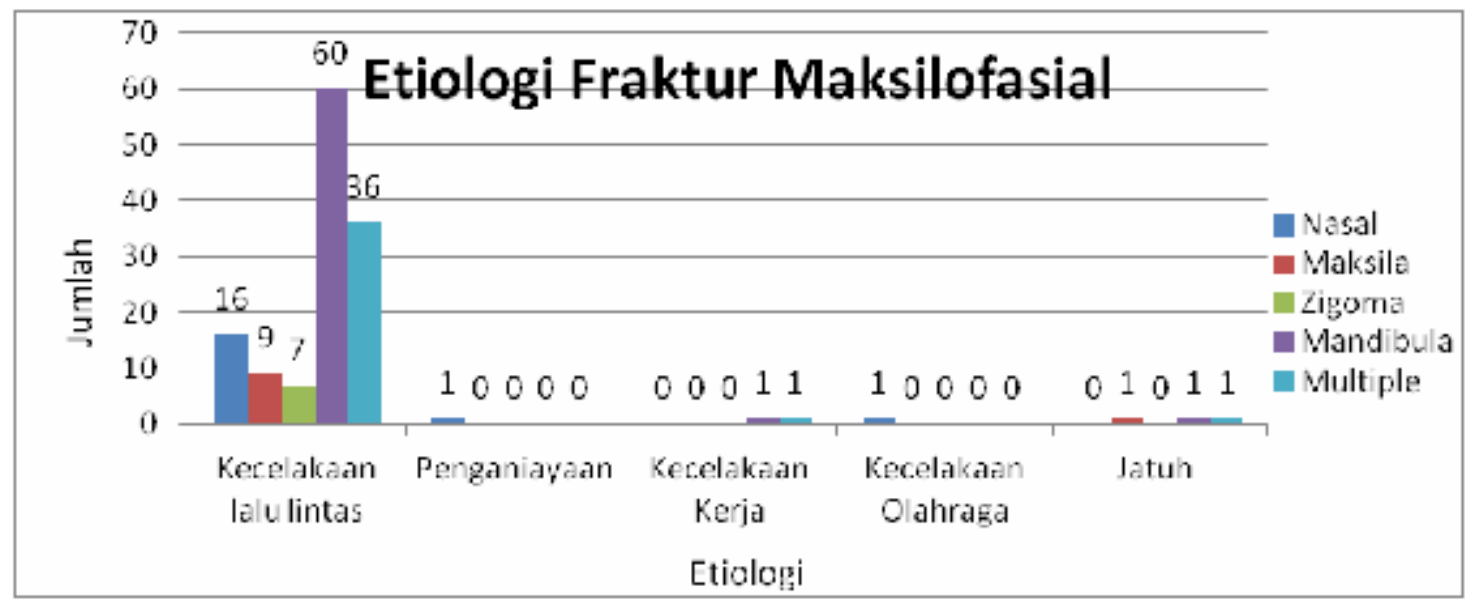


Diagram 4.4: Distribusi penderita fraktur maksilofasial berdasarkan jenis fraktur di RSUD Arifin Achmad Periode Januari 2009-Desember 2011.

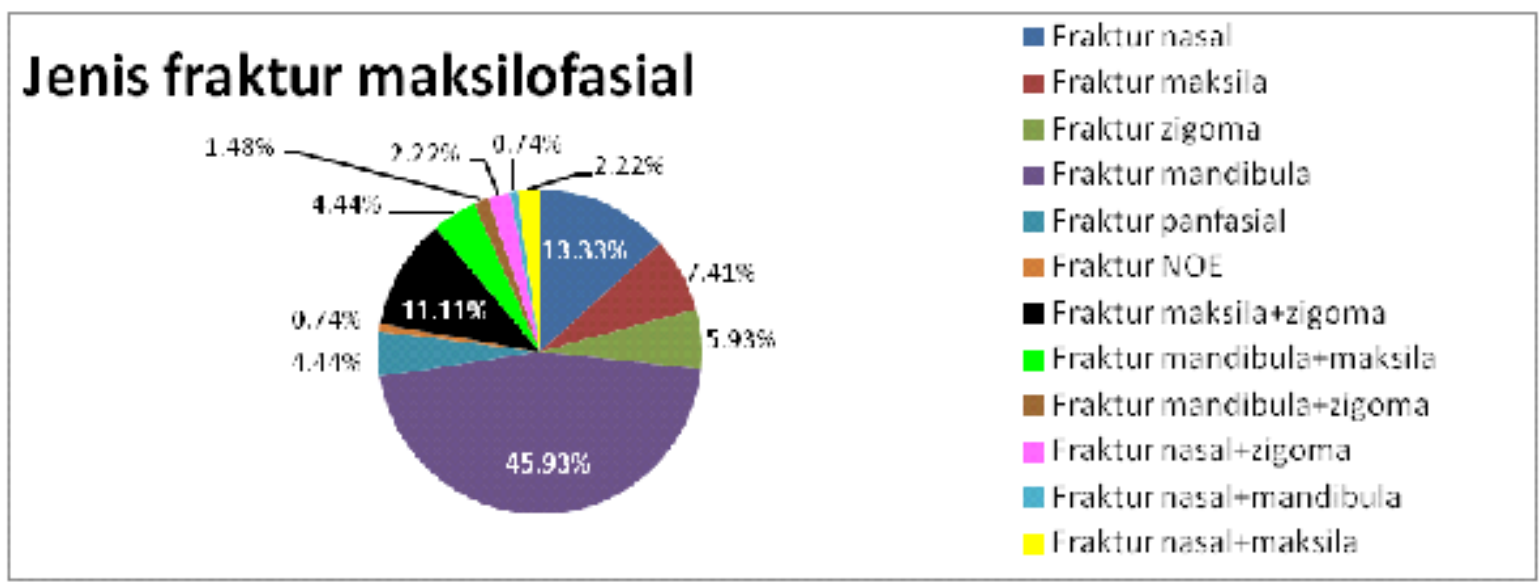

Diagram 4.5: Distribusi penderita fraktur maksilofasial berdasarkan gejala klinis di RSUD Arifin Achmad Periode Januari 2009-Desember 2011.

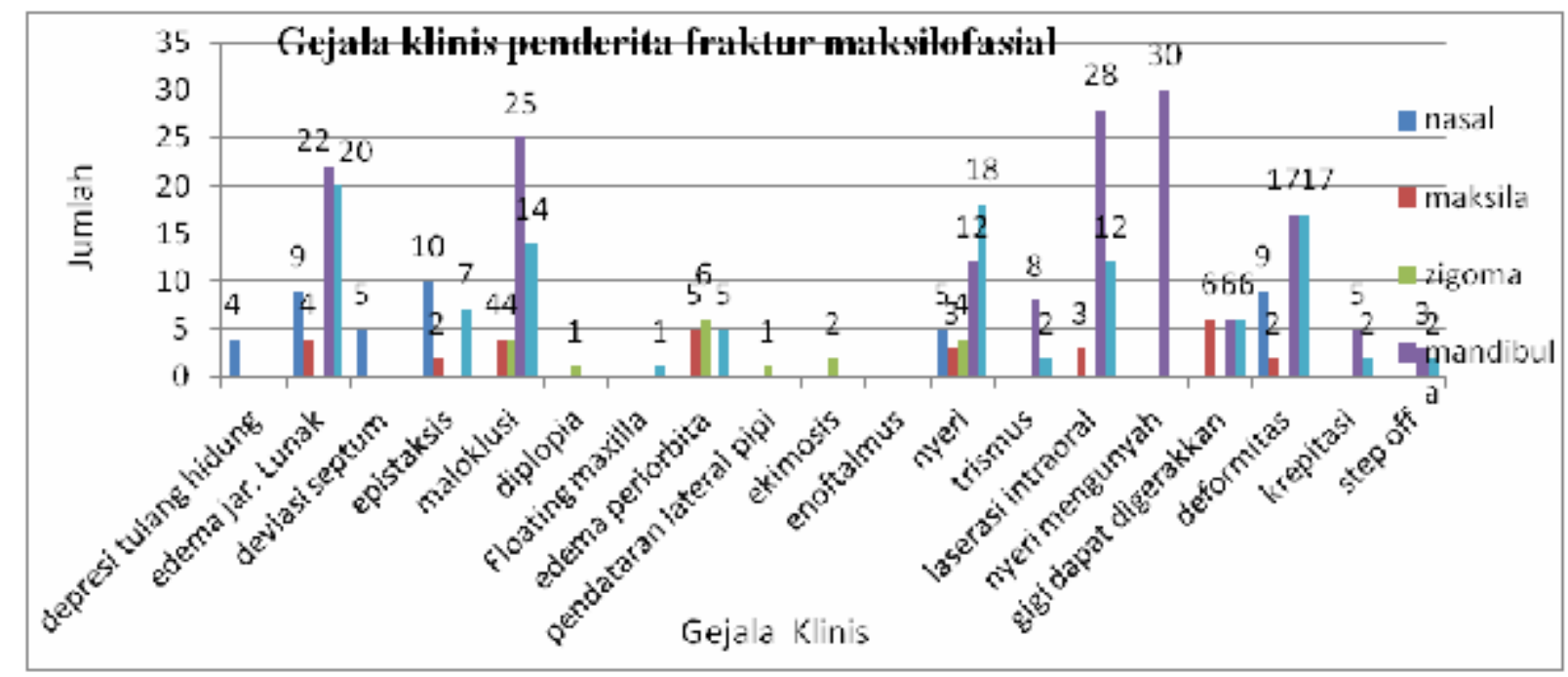

Diagram 4.6: Distribusi penderita fraktur maksilofasial berdasarkan jenis penatalaksanaan di RSUD Arifin Achmad Periode Januari 2009-Desember 2011.

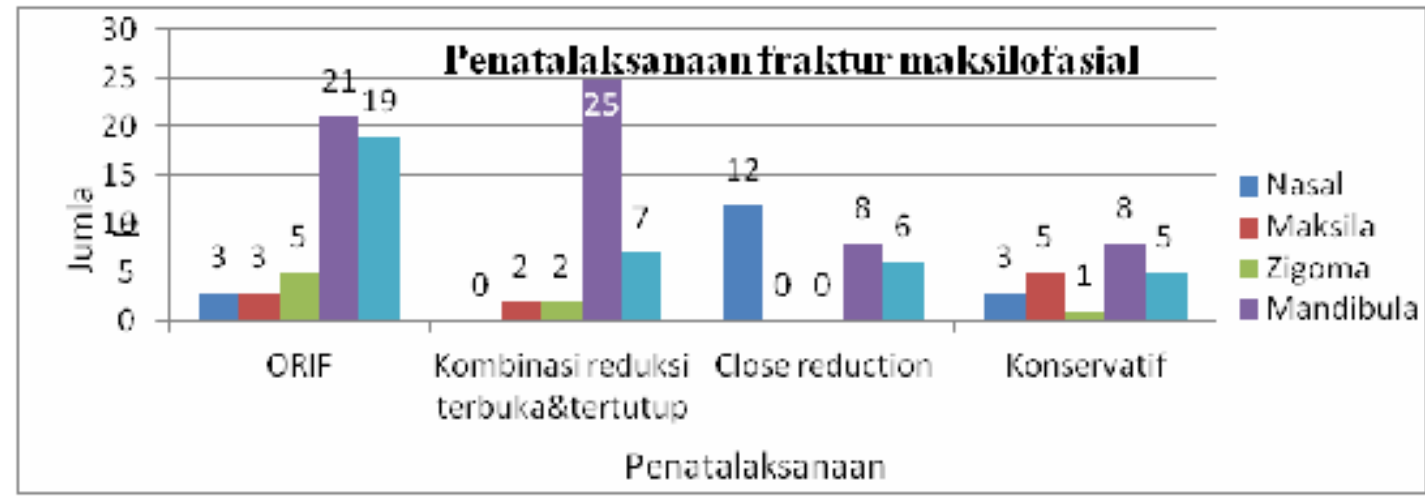




\section{PEMBAHASAN}

\section{Gambaran insidensi penderita fraktur maksilofasial di RSUD Arifin Achmad Pekanbaru, Periode Januari 2009 - Desember 2011}

Hasil penelitian distribusi penderita fraktur maksilofasial berdasarkan insidensi adalah sebanyak 195 orang menderita fraktur maksilofasial sedangkan jumlah penderita trauma secara keseluruhan adalah 3146 orang. Sehingga insidensi fraktur maksilofasial di RSUD Arifin Achmad Pekanbaru adalah 6,19\% dari seluruh trauma yang ditangani di Bagian Bedah RSUD Arifin Achmad Pekanbaru. Hal ini sesuai dengan data penelitian retrospektif tahun 2001-2005 yang menunjukkan bahwa angka kejadian fraktur maksilofasial $6 \%$ dari seluruh trauma yang ditangani oleh SMF Ilmu Bedah RSUD Dr. Soetomo, Surabaya.,

Angka kejadian fraktur mandibula menempati urutan pertama dari seluruh kasus fraktur maksilofasial yaitu berjumlah 62 kasus $(45,92 \%)$, diikuti dengan fraktur nasal 18 kasus (13,33\%), fraktur maksila 10 kasus $(2,96 \%)$, fraktur zigoma 8 kasus $(5,92 \%)$, fraktur panfasial 6 kasus $(4,44 \%)$ dan fraktur maksilofasial kombinasi lainnya sebanyak 31 kasus $(22,22 \%)$. Hal ini sesuai dengan penelitian di RSUD Dr. Soetomo (1991-1995)yaitu dari 102 fraktur maksilofasial ditemukan angka kejadian fraktur mandibula menempati urutan pertama $(58,82$ $\%) .{ }^{1}$

Pada penelitian ini didapatkan jumlah penderita fraktur maksilofasial sebanyak 117 kasus $(86,67 \%)$ adalah laki-laki dan perempuan sebanyak 18 kasus $(13,33 \%)$, sehingga diperoleh rasio antara laki-laki dan perempuan sebesar 6,5:1.Menurut penelitian Reksoprawiro (2006) perbandingan pria dan wanita yang mengalami fraktur maksilofasial adalah 6:1. ${ }^{5,6}$ Penelitian di Royal Adelaide Hospital, Australia (1989-1992) perbandingan laki-laki dan perempuan adalah $4: 1$, sedangkan penelitian di Waikato Hospital, New Zealand (2000) $80 \%$ penderita fraktur maksilofasial adalah lakilaki.Sesuai dengan kepustakaan bahwa insidensi fraktur maksilofasial terjadi lebih banyak pada lakilaki dari pada perempuan, hal ini karena laki-laki lebih banyak berada diluar rumah, sehingga lebih beresiko terjadi fraktur maksilofasial karena kegiatannya. ${ }^{1,7,9}$.
Dari semua kasus fraktur maksilofasial pada penelitian ini, ditemukan bahwa kelompok umur terbanyak adalah 11-20 tahun $(39,26 \%)$ disusul kelompok usia 21-30 tahun $(27,41 \%)$. Hal ini dikarenakan Provinsi Riau, khususnya Kota Pekanbaru termasuk kota yang sedang berkembang sehingga didominasi penduduk usia remaja hingga dewasa muda. Hal ini didukung juga oleh data dari Badan Pusat Statistik Kota Pekanbaru yang menyebutkan bahwa penduduk Pekanbaru lebih banyak didominasi oleh kelompok usia remaja hingga dewasa muda $(32,40 \%) .{ }^{10}$ Penelitian lain juga tidak berbeda jauh yaitu penelitian oleh Hwang (2010) di Rumah Sakit Pendidikan Universitas Inha, Korea Selatan bahwa morbiditas tertinggi pada fraktur maksilofasial dialami oleh kelompok umur 21-30 tahun (29\%), berbeda dengan penelitian Erol (2002) dari tahun 1978-2002 di Bagian Bedah Mulut dan Maksilofasial, Fakultas Kedokteran Gigi Universitas Dicle, Turki bahwa fraktur maksilofasial paling banyak ditemukan pada usia anak-anak yaitu 0-10 tahun $(27,6 \%)$, terutama pada musim panas karena anak-anak berlibur dan banyak bermain diluar rumah sehingga lebih beresiko untuk jatuh dan terjadi fraktur maksilofasial. ${ }^{7,8}$ Sedangkan penelitian di Royal Adelaide Hospital, Australia bahwa penderita fraktur maksilofasial terbanyak adalah kelompok usia 20-29 tahun. ${ }^{1}$

Hasil penelitian ini memperlihatkan bahwa, tingginya angka kejadian fraktur maksilofasial pada kelompok usia anak-anak, remaja hingga dewasa muda karena kelompok ini merupakan kelompok usia yang aktif dan produktif dalam melakukan aktifitas sehari-hari terutama menyangkut mobilitas/ perpindahan menggunakan kendaraan bermotor terutama roda dua. Golongan usia terbanyak pada penelitian ini berbeda dengan penelitian di negara lain karena perbedaan demografis di masing-masing tempat.

Penyebab fraktur maksilofasialterbanyak pada penelitian ini adalah karena kecelakaan lalulintas $(94,81 \%)$ yang sebagian besar karena kecelakaan sepeda motor $(81,48 \%)$ sesuai penelitian Sukerena (1983) penyebab terbanyak adalah kecelakaan lalu lintas $(82,46 \%)$ dan sebagian besar adalah pengendara sepeda motor $(61,49 \%)$. Hal ini juga serupa dengan penelitian di Rumah Sakit Al Qassi Sharjah, Uni Emirat Arab dari tahun 1999-2002 oleh 
Ahmed (2002) bahwa sebagian fraktur maksilofasial disebabkan oleh kecelakaan kendaraan bermotor (75\%). ${ }^{1,5,11}$ Penelitian lain di Royal Adelaide Hospital, penyebab terbanyak adalah akibat penganiayaan $(51,3 \%){ }^{1}$

Penelitian ini menunjukkan bahwa kecelakaan lalu lintas terutama oleh pengendara sepeda motor paling sering terjadi. Hal ini dikarenakan kurangnya perhatian pengendara tentang keselamatan jiwa mereka pada saat mengendarai sepeda motor di jalan raya, seperti tidak menggunakan pelindung kepala (helm), berkecepatan tinggi dan rendahnya kesadaran tentang beretika lalu lintas. Salah satu indikator meningkatnya angka kecelakaan lalu lintas, disebabkan pesatnya pertumbuhan jumlah kendaraan bermotor, terutama sepeda motor. Menurut data yang dihimpun Badan Pusat Statistik Republik Indonesia yang bersumber dari Kantor Kepolisian Republik Indonesia jumlah kendaraan bermotor diseluruh Indonesia pada tahun 2009 meningkat sekitar $287 \%$ dari tahun $2000 .{ }^{12}$

Akan tetapi hal ini berbeda dengan penelitian di negara lain seperti negara-negara 4 musim dengan jumlah kendaraan roda dua jauh lebih sedikit dibandingkan dengan Indonesia, sehingga sebagian besar penyebab fraktur maksilofasial adalah akibat penyerangan/kekerasan (assault) dan mabuk., ${ }^{9}$

Pada penelitian ini didapatkan angka kejadian fraktur mandibula menempati urutan pertama fraktur maksilofasial yang sering terjadi $(45,92 \%)$. Hal ini sesuai dengan berbagai penelitian lain dan kepustakaan lain yang menyebutkan angka kejadian mandibula rata-rata adalah 36-70\%. ${ }^{14}$ Penelitian Erol (2002) di Bagian Bedah Mulut dan Maksilofasial, Fakultas Kedokteran Gigi Universitas Dicle, Turki mendapatkan fraktur mandibula menempati urutan pertama sebanyak $72,8 \%$, pada penelitian Ssentongo(1994) di bagian kesehatan gigi di RS Lewanika, Zambiabahwa posisi pertama adalah fraktur mandibula sebanyak 67,6\%, kemudian penelitian Lee \& Snape (2006) di Christchurch Hospital, New Zealand fraktur mandibula pada posisi pertama sebanyak $45,8 \%$ dan penelitian Murtedjo dkk (1995) di RSUD Dr. Soetomo, mandibula adalah tulang wajah yang paling banyak mengalami fraktur $(58,8 \%),{ }^{1,8,13,15}$ Kesesuaian hasil penelitian ini juga didukung kepustakaan yang menyebutkan bahwa mandibula paling sering mengalami fraktur dibandingkan tulang wajah yang lain karena posisi mandibula yang terpisah dari kranium dan menonjol. ${ }^{14,16}$

Gejala klinis yang sering terjadi pada fraktur maksilofasial dari 135 kasus adalah edema jaringan lunak $(15,32 \%)$, epistaksis $(12,90 \%)$ kemudian deformitas dan maloklusi masing-masing sebesar $12,09 \%$. Menurut kepustakaan, sebagian fraktur maksilofasial berhubungan dengan luka-luka dan trauma pada jaringan lunak wajah dan leher yang mengakibatkan terjadinya edema, yang biasanya bersifat sementara. $^{7}$

Penatalaksanaan yang diberikan pada 135 kasus fraktur maksilofasial terdiri dari operatif/ reduksi terbuka dengan Open Reduction and Internal Fixation dengan plate and screw maupun wire sebanyak 51 pasien $(37,78 \%)$ dan teknik kombinasi reduksi terbuka dan tertutup sebanyak 36 pasien (26,67\%), sedangkanclose reduction dilakukan pada 26 kasus $(19,26 \%)$ dan konservatif pada 22 kasus (16,29\%). Hasil penelitian ini sesuai dengan penelitian Hwang (2007) di RS Pendidikan Universitas Inha, Korea Selatan yaitu penatalaksanaan dengan pembedahan masih merupakan modalitas penatalaksanaan utama yang digunakan (64\%), pada semua fraktur wajah kecuali fraktur nasal. ${ }^{7}$ Penelitian Lee dan Snape (2006) di Christchurch Hospital menyebutkan bahwa operasi terutama reduksi terbuka adalah tindakan paling banyak yang dilakukan pada pasien fraktur maksilofasial di Selandia baru yaitu sebanyak (44,4\%), penelitian lain oleh Erol (2002) di Bagian Bedah Mulut dan Maksilofasial Universitas Dicle juga mengungkapkan bahwa ORIF dengan fiksasi mini plate menjadi modalitas utama penanganan pasien fraktur maksilofasial $(44,5 \%) .{ }^{8,13}$

\section{KESIMPULAN}

Dari hasil penelitian dan pembahasan diperoleh simpulan bahwa:

1. jenis kelamin terbanyak penderita fraktur maksilofasial adalah pada laki-laki $(86,67 \%)$,

2. angka kejadian fraktur maksilofasial terbanyak adalah kelompok umur 11-20 tahun $(39,26 \%)$, disusul usia 21-30 tahun sebanyak 27,41\%. 
3. Penyebab fraktur maksilofasial terbanyak adalah karena kecelakaan lalu lintas $(94,81 \%)$ terutama kecelakaan sepeda motor $(81,48 \%)$.

4. Fraktur mandibula merupakan fraktur yang paling sering terjadi $(45,92 \%)$ karena posisinya yang menonjol dan terpisah dari kranium.

5. Gejala klinis yang paling sering terjadi adalah edema jaringan lunak $(15,13 \%)$, epistaksis $(12,90 \%)$ kemudian deformitas dan maloklusi masing-masing sebesar $12,09 \%$.

6. Penatalaksanaan pasien fraktur maksilofasial terbanyak adalah operatif/reduksi terbuka dengan Open Reduction and Internal Fixation dengan plate and screw maupun wire sebanyak 51 pasien $(37,78 \%)$ dan teknik kombinasi reduksi terbuka dan tertutup sebanyak 36 pasien $(26,67 \%)$.

\section{DAFTAR PUSTAKA.}

1. Wijayahadi RY, Murtedjo U, Reksoprawiro U. Trauma maksilofasial diagnosis dan penatalaksanaanya. Surabaya: FK Univ. Airlangga; 2006.

2. Snell SR. Anatomi Klinik. Edisi 3. Jakarta: EGC, 1997:719-742.

3. Soepardi AE, Iskandar N, Bashiruddin J, Restu DR. Buku Ajar Ilmu Kesehatan Telinga Hidung Tenggorok Kepala dan Leher. Edisi 6. Jakarta: Balai Penerbit FK UI; 2009. p. 199-207.

4. N. Fauzi Muchlis. Insidensi Fraktur Maksilofasial Akibat Kecelakaan Lalu Lintas pada Pengendara Sepeda Motor yang Dirawat di RSUP H. Adam Malik Medan. (Skripsi). Medan: FKG USU, Dept. Ilmu Bedah Mulut; 2010. Di unduh dari http://repository.usu.ac.id/ handle/123456789/21440 [diakses pada 27 Oktober 20111.

5. Reksoprawiro S. Epidemiologi Fraktur Maksilafasial (PPT). Surabaya: Divisi Bedah Kepala Leher, Bagian/SMF Ilmu Bedah. FK Unair/RSU Soetomo Surabaya. Di unduh dari: h t t p : / / w w w.g o o g l e.co.id / url ? s a =t\&rct $=\mathrm{j} \& \mathrm{q}=\mathrm{ppt} \% 20 \mathrm{trauma} \%$ 20maksilofasial $\% 20 \mathrm{rs} \% 20$ surabaya\&source $=$ web\&cd $=$ $1 \&$ ved $=0$ CBoQFjAA\&url=http $\% 3 \mathrm{~A} \%$
$2 \mathrm{~F} \% 2 \mathrm{Fimages} . \mathrm{kepalaleher.mu}$ ltiply.multiplycontent.com\%2Fattachment $\% 2 \mathrm{~F} 0 \%$ 2FSScFQA oKCscAAG41Rng 1\%2F01\% 2520Epidemiolog \%25200\% $\% 2520$ Maxillofacial\%2520 Fradure\%2520\%2520SNT.ppt\%3Fkey\%3D kepalaleher\%3 Ajournal\%3A68\%26nmid\%3D 137448 $452 \&$ ei $=$ v 5 DuTprLCYXYrQehyK D 9 C A \& u s g = A F Q j C N H o g 9 p 6XXnyJNuDi3GhhNzST9S8dQ\&cad=rja[diakses pada 16 November 2011].

6. Reksoprawiro S. Simposia Bedah Kepala Leher "Penggunaan Miniplate pada Penatalaksanaan Fraktur Maxilofacial". Majalah Farmacia Edisi Agustus 2007: 56. Diunduh dari :http:// www.majalah-farmacia.com/rubrik/ one news.asp? IDNews $=554$ [diakses pada 10 November 2011].

7. Hwang K, You SH. Analysis of Facial Bone Fracture: An 11 Years Study of 2094 Patients. Indian Journal of Plastic Surgeons. 2011; 43(1): $\begin{array}{llllllllllll}4 & 2 & - & 4 & 8 & \text {. } & \text { c } & \text { i } & \text { t } & \text { e } & \text { d }\end{array}$ 2011 November 16]. Available from: http:// www.ijps.org/article.asp?issn=0970-0358:year= $\begin{array}{lllllllllll}2 & 0 & 1 & 0 & ; & \mathrm{v} & \mathrm{o} & \mathrm{l} & \mathrm{u} & \mathrm{m} & \mathrm{e}\end{array}$ $=43$; issue $=1$; ppage $=42$; epage $=48$; aulast $=$ Hwang

8. Erol B, et all. Maxillofacial Fractures, Analysis of Demographic Distribution and Treatment in 2901 Patient (25 years ekperience). Journal of Cranio- Maxillofacial Surgery. 2004;32:308-313. [cited 2011 Nov 12]. Available from: http:// faculty.ksu.edu.sa/hkhalil/Selectedarticles/ Maxillofacial \%20 Fractures.\% 20Analysis $\% 20$ of $\%$ 20demographic $\%$ 20distribution\%20and.pdf

9. Buchanan J, et all. Maxilofacial Fractures at Waikato Hospital, New Zealand: 1989-2000. Journal of the New Zealand Medical Association, 2005 June 24, Vol 118 No 1217. [cited 2011 Nov 12]. Available from: http://journal.nzma.org.nz/ journal/118-1217/1529/

10.Badan Pusat Statistik Kota Pekanbaru. Jumlah Penduduk Kota Pekanbaru Dirinci Menurut Kelompok Umur dan Jenis Kelamin Tahun 2010. Diunduh dari :-http://www.slideshare.net/ bps1471/jumlah-penduduk-kota-pekanbarumenurut-kelompok-umur-dan-jenis-kelamin$\underline{\operatorname{tahun}-2010}$ 
11. Ahmed A. Pattern of Maxillofacial Fracture in Sharjah, Uni Emirat Arab: review from 230 Cases. Oral Surgeon. Agustus 2004; 98 (2): 16670 [cited 2012 February 27]. Available from: http://www.ncbi.nlm.nih.gov/pubmed/ $15316543 \&$ u s g $=$ A L k J r h h O qA0SzJTdPOSmKF-eQw7RN9e-A

12.Badan Pusat Statistik Republik Indonesia. Perkembangan Jumlah Kendaraan Bermotor Menurut Jenis Tahun 1987-2009. Diunduh dari : http://www.bps.go.id/tab sub/view.php? tabel $=1 \&$ daftar $=1 \&$ id subyek $=17 \&$ notab $=12$

13.Lee K.H, Snape L. Role of Alcohol in Maxillofacial Fractures. Journal of New Zealand Medical Association. 2008April 4, Vol121 N.1271. [cited 2011 Nov 12]. Available from:http://journal.nzma.org.nz/journal/121$\underline{1217 / 2978 /}$
14.Laub D.R. Mandibular Fractures. Juni 20 2011 [cited 2012February 27]. Available from: http://emedicine. medscape.com/article/1283150-overview \#showall

15.Ssentongo. Maxillofacial Fractures in Western Province Zambia, An 18 Months Study. 1994. Available from : http://www.santetropicale.com/ resume/17304.

16.Greenberg IM. Teks-Atlas Kedokteran Kedaruratan Jilid I dan II. Jakarta: Erlangga, 2008. 